\title{
Teachers' Beliefs on Students' Home Language as a Resource in EFL Classroom
}

\author{
Uma Nath Sharma \\ Tribhuvan University, Nepal \\ unsharma24@gmail.com
}

\begin{abstract}
This is the age of multilingual turn. It advocates the inclusion of indigenous languages that the children bring to school from home as resource. At present, use of students' home language as a resource in teaching and learning of a new language has become a vexing issue. The teachers' beliefs on any issue determine the types of teaching learning activities that they use in the classroom. In this context, this paper aims at exploring the Nepalese English language teachers' beliefs regarding the use of students' home language in English as a foreign language (EFL) classroom, and why or how they form their respective beliefs. For this, I collected data from five 'Grade ten' English language teachers of different community schools in Kathmandu, taking in-depth interview with them. The data were analyzed qualitatively creating themes. The analysis shows that the English language teachers regard home language as a resource in EFL classroom, and they do so on the basis of their own theoretical understanding and practical experience in teaching.
\end{abstract}

Keywords: home language, EFL classroom, resource, foreign language teaching

\section{Introduction}

English is taught as a foreign language in Nepal. The children have little or no exposure to English and no literacy in it before entering the formal schooling. Almost all the Nepalese school children use a language other than English as their home language, the language or languages predominantly spoken in the students' home for purposes other than academic learning. Their teachers also are from non-native English background; and most of them have at least one home language common to their students. The children start learning English from the very beginning of their schooling in both institutional and community schools in Nepal. That is to say, English has been introduced from the very beginning of primary education, i.e. from Grade one, since 2005 AD, and it is supposed to be taught solely in English that is without using students' mother tongue or home language in accordance with the declared policy (see Curriculum Development Centre [CDC], 2063 BS. 
Some experts in foreign language teaching do not agree on the use of home language in EFL classrooms. Some people argue that the amount of target language $(\mathrm{TL})$ input is important in foreign language ( $\mathrm{FL}$ ) teaching and learning context because little opportunity exists for exposure to the TL outside the classroom whereas some others argue for the utilization of students' home language as a resource in EFL classrooms. That is to say, some experts in FL teaching argue that using overuse of home language or L1 in EFL classroom may result in students' desire to turn back to it all the time whereas some others maintain that the use of home language may contribute to FL learning process (Karaagac, 2014).

Turnbull and Arnett (2002), for example, argue that maximizing the TL in the classroom is a favourable practice.This view ignores the sociocultural theory of learning, which maintains that language acquisition takes place when a learner constructs meaning through social interaction and cooperation. The meaning making process can be mediated through the use of home language.

On the other hand, Phyak (2016) has maintained that the multilingual learners' fluid, dynamic, and heterogeneous multilingual practices, such as translanguaging and translation should be recognized as legitimate knowledge in education. "Educational failure of linguistic minorities all over the world is primarily related to the mismatch between the home language and the language of formal instruction" (Mohanty, Mishra, Reddy, \& Ramesh, 2009, p. 283). This implies that the failure of linguistic minority people can be reduced by using their home language in schools as a resource in teaching and learning of language and content. In this regard, Paker and Karaagac (2015) remark that "the use of mother tongue (L1), i.e. home language has been an inevitable part of second or foreign language teaching in various contexts where both the teachers and the learners have the same mother tongue" (p. 112). It is true especially in the situations; when the students are learning English in their native place or country, when the teacher is non-native speaker of it, and if the students are beginner learners of English or relatively weak in English.

Usually, all of the above-mentioned situations exist in community schools of Nepal. Therefore, the use of students' home language naturally occurs to some extent in EFL classrooms no matter whatever be declared in "macro-level language policy" (Hornberger \& Johnson, 2011, p. 278) of Nepal. In this context, Baker and Wright (2017) contend that "when a student cannot cope with processing in their second or third language, then they naturally turn to their first language for thinking, to find answers and to be cognitively successful" (p. 281). This means preventing students from utilizing their first or home language means depriving 
them of an invaluable cognitive tool (Swain \& Lapkin, 2000). Perhaps, there is no one who does not use their home language as a thinking tool for learning a second or foreign language.

The above discussion shows that there is contrast among policy, practice and theory, and even among the theories regarding the use of home language in education in general, and language education in particular. In such a situation, how can the teachers and students be expected to know what to do in the classroom? In this context, this paper attempts to explore what the Nepalese English language teachers think or believe on the use of home language as a resource in their English language teaching classroom, i.e. in EFL classroom, and why or how they form their respective beliefs. For this, the following research questions were addressed:

1. What are the Nepalese English language teachers' beliefs on the use of home language as a resource in EFL classroom?

2. How do the teachers form the respective beliefs?

\section{Methodology}

For this study, I used qualitative cross-sectional research design in terms of both population and duration of research. I collected data in terms of words through in-depth interview with the participants, and analyzed them thematically. The research paradigm I adopted was constructivism, which holds the belief that there are multiple realities, and the knowledge of reality can be co-constructed by all research participants and the researcher.

The participants of the study comprised five 'Grade ten' English language teachers (one from each purposively selected school) teaching in community schools in Kathmandu district. Four of the participant teachers were M. Ed. in English education, and one was M. A., B. Ed.

For the collection of required data, I took in-depth interview with the selected teachers, on the basis of interview guideline (see Appendix) as the tool. The interviews were digitally recorded and transcribed. Then, I analyzed the data thematically utilizing the tool of "thematic networks" (Attride-Stirling, 2001).

\section{Results and Discussion}

The results have been presented and discussed under the following themes corresponding the main themes in the interview guideline (see Appendix). 


\section{Knowledge of home language as the foundation for learning a new} language. It is argued that any new language can be learnt on the foundation of home language. The participant teachers contend that the knowledge of home language can be the foundation for learning a second or foreign language. They opined that the knowledge of academic function in one language can be the foundation for learning the corresponding academic functions in another language, and therefore students' knowledge of their home language is an advantage for learning a new language.

As stated by one of the teachers, he found that the students who are good in Nepali are also good in English as the test results show. He further explained that non-Nepali native speakers, such as some Tamang and Newar students who are relatively weak in Nepali, which is one of their home languages, are weak in English as well. Another teacher shared his experience that the indigenous learners, who have possessed good knowledge in their home languages including Nepali are found to be good in English and other content subjects.

The teachers gave examples of possible transformation of knowledge of content in Nepali to English. Some teachers argued that if the learners of English are able to write an essay in Nepali or in any other language, they can be more easily taught to write an essay in English. Other teachers added that it is true only when the topic is the same. For example, as opined by a teacher, if learners can write an essay on Dashain festival in Nepali they can easily understand and learn to write an essay on that topic in English as well.

The teachers' views in this regard are in line with Cummins, Early, and Stille's (2011) remark that "...when teachers expand the pedagogical space from a monolingual to a multilingual zone, even newcomer students with minimal English can use language to generate new knowledge, create literature and art, and act on social realities" (p. 42).

The teachers' recognition and respect for students' home languages in classrooms may lead home language towards becoming an asset not only in learning a second language but also in a person's life as a whole. Use of home languages in classrooms maintains multilingualism, and "a successful multilingualism policy can strengthen life chances of citizens" (European Commission, 2008, as cited in Gearon, Miller,\& Krostogriz, 2009) in the present globalized world. This means that proper planning and management of home languages existing in a community or school makes it not only a resource in teaching and learning of language and content but also a life-long asset to the people of the community. 
Usefulness of students' prior linguistic knowledge. Pre-existing knowlwdge of any kind can be a foundation for further learning (Baker \& Wright, 2017). This can be true of linguistic knowledge as well. The informant teachers believed that the learners' prior knowledge of other languages is useful in teaching and learning of English. It is illustrated in one of the teachers' talk of universal pattern of language. This concept is related to Chomsky's (2006) concept of "universal grammar". Another teacher said that this is true specially when there is similarity between the known language(s) and the TL (here English). This refers to Lado's (1957) theory of contrastive analysis that assumes that "the comparison between native and foreign language is the key to ease or difficulty in foreign language learning" (p. 1). That is to say, it is easy to learn the language item in a second or foreign language if it is similar to corresponding language item in the learner's home language, and is difficult in case of difference. Another teacher argued that the more linguistic knowledge of one or more languages one has, the more interested or motivated he/she becomes in learning a new language irrespective of similarity and/or differences. He added, "I have found it true especially if the students have linguistic knowledge of Nepali. One (Tamang) teacher said that it was her experience that her knowledge of Tamang and Nepali grammar made her easier to understand the grammar of English in relation to her only Nepali speaking classmates".

The teachers also reported that they draw on students' prior knowledge of Nepali language. One Tamang teacher claimed that she draws on students' knowledge of Nepali and Tamang. She reported that she asks her students to think and express in Nepali or Tamang about the topic of discussion, and then starts teaching in English. Other teachers said that they draw on their students' knowledge of Nepali but not of other languages. They thought that this is justifiable because all of their Grade ten students speak and understand Nepali well.

The teachers said that they like the learners to bring knowledge from their home language. One teacher wanted his students to bring content in their language. Some teachers wanted to bring their students' knowledge about their cultures, such as religion, festivals, and other rituals into the classroom. Another teacher expressed his opinion that the students' knowledge of grammar of their own language is helpful to understand English grammar.

For the teachers, the knowledge of home or first language hinders as well as facilitates second or foreign language learning. They said that it depends on similarities or differences between the languages. However, they maintained that the net result is facilitation rather than hinderance. That is to say, facilitation 
exceeds hindrance irrespective of similarity or difference.

The teachers' belief that the learners' prior linguistic knowledge is helpful in teaching and learning of a new language can be linked with Cummins' (2007) theory of "Engaging prior understandings". According to him "The role of prior knowledge is particularly relevant to the issue of teaching for cross-linguistic transfer because if prior knowledge is encoded in students' L1, then the engagement of prior knowledge is inevitably mediated through L1" (p. 232). All sorts of prior knowledge, whatever language it is coded in, is helpful in later learning. In case of second or foreign language learning, if the prior knowledge is encoded in students' first language then the engagement of prior knowledge should be mediated through the first language, which is obviously their home language.

Use of translanguaging in the classroom. Translanguaging is a pedagogical practice where two languages usually the students' home language and the TL are used alternately for different tasks or activities. For example, students might be asked to read in English and write in their home language or viceversa. The teachers (except one) reported that they had not heard the term "translanguaging" yet. However, they are found using activities in line with translanguaging in the classroom. The teachers argued that bilingual people use two languages simultaneously. In this context, no teacher is found to support monolingual teaching in bilingual or multilingual classroom setting. No teacher supported the strict only English policy in EFL classroom. The informants strongly revolted against not allowing students to speak Nepali or other home languages in the classroom or within the school premise.

The teachers thought that there is no gain in learning a new language (here English) in the cost of a home language (especially Nepali in context of Nepal). One of the teachers regarded it as general truth that ' $-1+1=0$ '. This implies that the teachers are aware of the importance of recognizing and valuing their students' home language and culture in education.

Usefulness of students' prior language learning experience. The informants agreed with the important role of learning how to learn a language in language curriculum. Two teachers said that they teach how to learn English. One of them stated that he asks his students to use internet, to listen to English programmes in FM radio, and to watch TV or other video programmes in English. Another teacher remarked that he asks his students to speak English with friends and family members as far as possible as a strategy for learning English. 
The teachers theoretically support that it is useful to draw on students' language learning experience of other languages when learning English. They gave examples from grammar. They argued that the students' experience of learning Nepali Grammar can be useful in learning English grammar.

Students' prior language learning experience can be kept under their prior knowledge, and therefore can have a linkage with later learning of language or content. Thus, the usefulness of students' prior language learning can be supported by Cummins' (2007) theory of "Engaging prior understandings" discussed earlier.

Collaboration with 'home language' teacher. The teachers reported their good relationship with Nepali teacher (i.e., teacher of Nepali language), such as they talk to each other frequently, have breakfast together and they know/have each other's phone numbers, and so on. The teachers remarked that they consulted each other specially while teaching grammar. One of the teachers expressed his bitter experience that teachers hesitate to collaborate with others, to learn from each other. However, all the teachers regarded the collaboration between teachers a good idea. They realized that there should be collaboration between all the language teachers and even with other subject teachers. Teachers are learners as well, and "collaboration and cooperation are how learning occurs" (Denos, Toohey, Neilson, \& Waterstone, 2009, p. 46). Collaboration makes possible what is impossible to do alone.

Need for drawing on students' knowledge in activities in the textbook. The teachers reported that they have not found any activities or topics in the textbook in which students are required to draw on what they know before except the topic "Jitiya", a Tharu festival. They said that such a cultural topic makes the students belonging to the cultural group feel proud, they may feel respected and recognized. They also added that the textbook activities should represent as many Nepalese cultures as possible. Their view can be linked to Holliday's (2010) concept of culture-sensitive approach to language teaching, which deals with making the methodologies and materials appropriate to the culture of the host educational environment.

To sum up the results and discussion, the participant teachers have positive attitude towards using home language as a resource in EFL classroom. They were found to develop such a positive attitude towards the use of home language in EFL classroom on the basis of their own theoretical understanding and practical experience in teaching English as a foreign language. 


\section{Conclusion}

The participant teachers of this study appear highly positive towards using students' home language (and culture) as a resource in teaching and learning of English as a foreign language collaborating with 'other language' teachers. The teachers are aware of the importance of drawing on diverse prior linguistic and cultural knowledge the students bring to school or classroom from home or community. It is the fortune for a developing country like Nepal to have teachers highly positive towards using and valuing students' home languages in EFL classroom whereas Edwards (2010), in Western context, writes, "I have been amazed and disappointed at how ill-prepared teachers typically are with regard to linguistic and cultural variation in the classroom. The education of teachers generally involves very little exposure to this sort of heterogeneity" (p. 1).

The explanations of the way they form their beliefs regarding the use of home language as a resource reflect their sound theoretical knowledge and practical experience. However, some teachers still have to develop the idea of translating the theory into classroom practice.

\section{Acknowledgements}

This study was funded by Research Management Cell of Mahendra Ratna Campus, Tahachal, Kathmandu. I am grateful to the Research Management Cell for providing me with the fund for the study. I would like to extend my gratitude to the anonymous reviewers and the editor(s) for their invaluable comments and suggestions.

\section{References}

Attride-Stirling, J. (2001). Thematic networks: An analytic tool for qualitative research. Qualitative Research, 1(3), 385-405.

Chomsky, N. (2006). Language and mind (3rd ed.). Cambridge: Cambrridge University Press. Retrieved July 23, 2018, from http://download1.libgen.io/ads. php?md5=99B5B9D0DAB2CEE5E8079F2A67B38FFA

Cummins, J., Early, M., \& Stille, S. (2011). Frames of reference: Identity texts in perspective. In Identity texts: The collaborative creation of power in multilingual schools (pp. 21-43). Stoke on Trent: Trentham Books. Retrieved April 22, 2018, from http:// download1.libgen.io/ads.php?md5=26667D67A0459FA20D8E906411BA4382

Curriculum Development Centre [CDC]. (2063 BS). Prathamik shiksha pathyakram 2062: Kaksha 1-3 [Primary education curriculum 2062: Grade 1-3]. Sanothimi, Bhaktapur: Author. 
Denos, C., Toohey, K., Neilson, K., \& Waterstone, B. (2009). Collaborative research in multilingual classrooms. Bristol: Multilingual Matters. Retrieved August 24, 2018, from http://b-ok.xyz/book/810736/349ef5

Edwards, J. (2010). Language diversity in the classroom. Bristal: Multilingual Matters.

Gearon, M., Miller, J., \& Krostogriz, A. (2009). The challenges of diversity in language education. In J. Miller, A. Kostogriz, \& M. Gearon. (Eds), Culturally and linguistically diverse classrooms (pp. 3-17). Bristol: Multilingual Matters.

Holliday, A. (2010). Appropriate methodology and social context . Cambridge: Cambridge University Press.

Karaagac, O. (2014). The use and functions of mother tongue in EFL classes. (Unpublished master's thesis), English Language Teaching Department, Department of Foreign Language Teaching, Institute of Educational Sciences, Pamukkle University, Denizli.

Lado, R. (1957). Linguistics across culture: Applied linguistics for language teachers. Michigan: The University of Michigan Press.

Mohanty, A. K., Mishra, M. K., Reddy, N. U., \& Ramesh, G. (2009). Overcoming the language barrier for tribal children: Multilingual education in Andhra Pradesh and Orissa, India. In T. Skutnabb-Kangas, R. Phillipson, A. K. Mohanty, \& M. Panda (Eds.), Social justice through multilingual education (pp. 283-297). Bristol: Multilingual Matters.

Paker, T., \& Karaagac, O. (2015). The use and functions of mother tongue in EFL classes. Procedia - Social and Behavioural Sciences, 199, 111-119. Retrieved from https:// booksc.xyz/book/54634632/3d8b80

Phyak, P. (2016). 'For our cho:tlung': Decolonizing language ideologies and (re)examining multilingual education polcies and practices in Nepal. (Unpublished doctoral dissertation), University of Hawai'i, Manoa.

Swain, M., \& Lapkin, S. (2000). Task-based second language learning: The uses of the first language. Language Teaching Research, 4(3), 251-274. 


\section{Appendix}

\section{Guidelines for Interview with the Teachers}

\section{Preliminary}

Name:

Qualification and training:

Languages you speak:

Languages you understand:

\section{Students' home language as an asset}

1. It is often heard that the knowledge of home language can be the foundation for learning a second or foreign language. What are your views about this saying? How or why do you think so?

2. It is said that the knowledge of academic functions in home language can be the foundation for learning the corresponding academic functions in a foreign language. What is your opinion about this view?

\section{Students' previous linguistic Knowledge}

3. To what extent do you think students' knowledge of other languages is useful for learning English? How or why do you think so?

4. To what extent do you draw on your students' knowledge of Nepali or other home languages when teaching English? How and why?

5. Is there knowledge from Nepali or other home languages of your students that you would have liked learners to bring into the English classroom? Mention and explain.

6. Some say that the knowledge of first or home language hinders second or foreign language learning, and some others say that the knowledge of first or home language facilitates second or foreign language learning. What do you think? Which exceeds another?

\section{Translanguaging}

7. It is said that bilingual people use two languages simultaneously, not necessarily separately. What is your view about this view?

8. What does your view imply in teaching English as a second or foreign language?

9. Do you apply this implication in your practice in teaching? How? 


\section{Students' language learning knowledge}

10. What do you think about the fact that learning how to learn a language is a central part of the language curriculum? Why?

11. To what extent do you spend time on teaching your students how to learn (learning strategies) English in your classroom? How and why?

12. Your students have already learned other languages, collectively called home language, before beginning to learn English. To what extent do you think it is useful to draw on students' language learning experiences when learning English? For example?

Language teacher collaboration

13. To what extent do you collaborate with Nepali or any 'other home language' teacher teaching the same students? When (i.e., in which condition) and how?

14. Do you have any suggestions regarding what topics English and Nepali language teachers might collaborate on across the subjects?

\section{Learning materials}

15. Have you noticed any activities in Grade ten English textbook in which students are required to draw on what they know before, such as by exploring similarities and differences between languages or reflecting on which learning strategies can be transferred from Nepali or other home languages to English? 